\section{Alternatives to Methyl Bromide for Strawberry Runner Plant Production}

\author{
Zahangir Kabir, ${ }^{1}$ Steven A. Fennimore, ${ }^{1,2}$ and John M. Duniway ${ }^{3}$ \\ University of California-Davis, One Shields Ave, Davis, CA 95616
}

Frank N. Martin

U.S. Department of Agriculture, Agricultural Research Service, 1636 East

Alisal Street, Salinas, CA 93905

Gregory T. Browne ${ }^{3}$

U.S. Department of Agriculture, Agricultural Research Service, University of California-Davis, One Shields Avenue, Davis, CA 95616

Christopher Q. Winterbottom ${ }^{4}$

Sierra-Cascade Nursery Inc., Susanville, CA 96130

Husein A. Ajwa, ${ }^{1}$ Becky B. Westerdahl, ${ }^{5}$ and Rachael E. Goodhue ${ }^{6}$
University of California-Davis, One Shields Avenue, Davis, CA 95616

Milton J. Haar

University of Minnesota, 23669 130th Street, Lamberton, MN 56152

Additional index words. Fragaria $\times$ ananassa, methyl bromide, iodomethane, 1,3dichloropropene, dazomet, strawberry runner plant, strawberry yield, low elevation nursery, high elevation nursery

\begin{abstract}
For years, strawberry (Fragaria $\times$ ananassa L.) runner plant nurseries have relied on methyl bromide (MB) fumigation of soil to produce healthy transplants. Methyl bromide, however, has been phased out due to its environmental risks. The potential for alternative fumigants to replace MB was evaluated at low and high elevation strawberry nurseries in California. The alternative fumigant iodomethane plus chloropicrin (IMPic) and a nonfumigated control (NF) were compared to methyl bromide plus chloropicrin (MBPic) at a low elevation nursery (LEN) and at a high elevation nursery (HEN) near Susanville, Calif. At a HEN near Macdoel, Calif., MBPic was compared to alternative fumigants IMPic, 1,3dichloropropene plus chloropicrin mixture (Telone $\mathrm{C35}$ ) followed by dazomet, chloropicrin (Pic) followed by dazomet and NF. Plants produced at the LEN were transplanted at the Macdoel HEN to measure the effects of soil fumigant history on plant health and runner plant production. Plants produced at both high elevation nurseries were evaluated for fruit yield and quality at two commercial fruit production sites in soils previously fumigated with MBPic or Pic. Runner plant production at the nurseries was similar in plots fumigated with either MBPic or alternative fumigants. All fumigation treatments had higher runner plant production than plants produced for two production cycles on NF soils. Generally, fruit yields from nursery plants produced on soils fumigated with IMPic, Pic followed by dazomet, or Telone $\mathbf{C} 35$ followed by dazomet, were similar to fruit yields from plants produced on MBPic fumigated soils. Overall, our results indicate that preplant soil treatments with IMPic, Pic followed by dazomet, and Telone C35 followed by dazomet, are potential alternatives to MBPic fumigation for strawberry runner plant nurseries. Fruit yields by plants in MBPic and Pic fumigated soils were comparable; however, they were more variable in Pic fumigated soils. Chemical names used: 1,3-dichloropropene (1,3-D), methyl bromide, methyl iodide (iodomethane), trichloronitromethane (chloropicrin), tetrahydro-3, 5-dimethyl-2 H-1,3,5-thiadiazine-2-thione (dazomet).
\end{abstract}

Effective soil fumigation for management of soilborne pests is the cornerstone

of the current strawberry production system in California, and control of a wide range of

Received for publication 4 Feb. 2005. Accepted for publication 8 May 2005. Financial support was provided by the USDA-CSREES Methyl Bromide Transitions Program(00-51102-9553, 2002-51102-01929). Material support was provided by the California Strawberry Commission, Lassen Canyon Nursery, Sierra-Cascade Nursery, Coastal Berry, Martinez Berry and Sea Crest Farms. The cooperation of Cecil Martinez, Stuart Yamamoto, Gary Williamson, Scott Scholer and Glenn Imoto is gratefully acknowledged. Thanks to Doug Dopkins and Luis Gurerro for technical help.

${ }^{1}$ Department of Plant Sciences.

${ }^{2}$ To whom reprint requests should be addressed; email safennimore@ucdavis.edu.

${ }^{3}$ Department of Plant Pathology.

${ }^{4}$ Formerly of the California Strawberry Commission, Watsonville.

${ }^{5}$ Department of Nematology.

${ }^{6}$ Department of Agricultural and Resource Economics. soilborne pests is imperative if the current level of productivity is to be maintained. The diversity of climates in California, along with the use of methyl bromide (MB) fumigation, permits the production of high-quality runner plants. California produces more than a billion strawberry runner transplants annually, with a total value of about $\$ 60$ million, of which about $20 \%$ are exported (CSC, 1999). Strawberry runner plant production is a multi-year and multi-location process that begins in virus-free rearing facilities (i.e., screen-houses). Plants are then vegetatively propagated in the field for one or two 8-month-long seasons at a low elevation $(<150 \mathrm{~m})$ nursery $(\mathrm{LEN})$ where favorable warm climatic conditions allow rapid plant propagation (Voth, 1989). Runner plants harvested in winter from the LEN are either planted as mother plants at a LEN for a second year of propagation or moved to a high elevation $(>1000 \mathrm{~m}$ ) nursery $(\mathrm{HEN})$ in northeastern California for the propagation of daughter runner plants intended for fruiting fields. Strawberry plants require adequate chilling to optimize the number of fruit branches for fruit production (Strand, 1994). At the HEN, cold night temperatures and short photoperiods reduce plant growth but increase subsequent plant vigor and productivity (Larson, 1994; Larson and Shaw, 2000; Voth and Bringhurst, 1990). Finally, during September to November, daughter runner plants are harvested at the HENs, sorted, trimmed, and chilled for an appropriate period in cold storage before planting in fruiting fields.

Beginning about 1960, methyl bromide (MB) became the foundation of soilborne disease and weed control in California strawberries (Wilhelm, 1966). Methyl bromide in combination with chloropicrin (Pic) (MBPic; Tri-Cal, Hollister, Calif.) controls weeds, soilborne pathogens and nematodes (Wilhelm and Paulus, 1980). Virtually all runner plant nurseries fumigate soil with MBPic to ensure pest-free planting stock. About $1.68 \times 10^{6} \mathrm{~kg}$ of MB was used in 2002 in California for preplant fumigation of strawberries representing about $50 \%$ of the total MB use in California (CDPR, 2002). About 23\% of MB used in California strawberries in 2002 was used for nursery fumigation (USDS, 2003). MB has been classified as a Class I stratospheric ozonedepleting chemical and use of MB was phased out under the Montreal Protocol (Anbar et al., 1996; U.S. EPA, 1993). Except for critical use exemptions, MB manufacture and import was banned 1 Jan. 2005 (Duniway, 2002).

The phase-out of MB could have serious negative economic consequences for California's strawberry industry. The industry accounted for $84 \%$ of the total U.S. gross sales in 2003 with a value of $\$ 1.1$ billion harvested from 11,900 ha (NASS, 2004). The USDAEconomic Research Service (USDA, 2000) estimates that without MB the fresh-market strawberry industry could lose more than $\$ 100$ million annually. Carter et al. (2005) estimated revenue losses of $7 \%$ to $15 \%$ of industry revenues, or $\$ 69.3$ to $\$ 148.5$ million based on 2002 revenues. The strawberry industry urgently needs effective alternatives for $\mathrm{MB}$ for soil fumigation. 
Potential alternatives to MB currently under investigation include Pic (trichloronitromethane, Niklor Chemcial Co., Long Beach, Calif.), iodomethane (methyl iodide, Midas, Arvesta, San Francisco, Calif.), 1,3-dichloropropene, (1,3-D, Telone, Dow AgroSciences, Redeck, N.C.), metam sodium (sodium $N$-methyl dithiocarbamate) and dazomet (tetrahydro-3, 5-dimethyl-2H-1, 3, 5-thiadiazine-2-thione, BASF, Research Triangle, N.C.). Chloropicrin has been applied in combination with MB since the late $1950 \mathrm{~s}$, but limited information is available regarding the effectiveness of Pic alone for control of soil pests in strawberry runner plant and fruit production fields (Wilhem, 1966). Application of Pic alone is likely to be effective against soilborne fungi and insects but less effective against nematodes and weeds (Johnson et al., 1979; Johnson and Feldmesser, 1987; Wilhelm and Paulus, 1980).

Iodomethane (IM) is analogous to $\mathrm{MB}$ chemically, but has a lower ozone depletion potential of 0.016 compared to 0.4 for $\mathrm{MB}$ (Ohr et al., 1996). Iodomethane is rapidly degraded by photolysis in the troposphere within 2 to $8 \mathrm{~d}$ whereas $\mathrm{MB}$ remains in the atmosphere for 0.7 years (NOAA, 2002). Chemically, IM is more stable than MB under field conditions with boiling points of $43^{\circ}$ and $4{ }^{\circ} \mathrm{C}$, respectively. Therefore, IM is liquid at usual ambient temperatures, whereas MB is a gas (Eayre et al., 2000). Iodomethane is 1.5 times more effective than MB in controlling weeds such as purple nutsedge (Zhang et al., 1997) and is as effective as MB for control of Verticillium wilt in strawberry (Duniway and Gubler, 1996), Rhizoctonia solani and the plant parasitic nematodes Meloidogyne incognita, Heterodera schachtii and Tylenchulus semipenetrans (Becker et al. 1998). Iodomethane can be used in combination with other fumigants such as Pic to increase its spectrum of activity against soil pests.

The fumigant, 1-3-dicloropropene (1,3-D), developed in 1943, has provided excellent control of nematodes, and has shown some activity on soilborne fungi and bacteria, but has little activity against weeds (Noling and Becker, 1994; Roby and Melichar, 1997). To broaden its biocidal activity and efficacy in controlling pests and weeds, 1,3-D is often used in combination with $35 \%$ Pic (Telone C 35 )
(CPR 2004). Telone C35 was found to be as effective as MBPic fumigation for strawberry production in California(Duniway et al., 1998). Dazomet (DZ) is a microgranular fumigant that controls soilborne fungi, bacteria, nematodes and weeds (Fritsch and Huber, 1995; Harris, 1991; Mappes, 1995). When incorporated into moist soil, DZ breaks down into several volatile compounds including methylisothiocyanate, which kills many soilborne organisms and weeds. Dazomet is not registered for use with food crops such as fruiting strawberries but can be used in nursery plant production (BASF, 1997).

Little information is available on the performance of alternative fumigants in strawberry nurseries. Therefore, this study was done to evaluate the efficacy of alternative fumigants for plant productivity and pest management in strawberry nursery fields. Because soil fumigation is used several times in the strawberry production system, alternative fumigants were evaluated at each stage. This allowed inferences to be made regarding the cumulative effects of alternative fumigants on runner plant yield and fruit production.

\section{Materials and Methods}

Plantmaterial. The variety 'Camarosa'was used in all experiments. 'Camarosa' was chosen because it accounts for about $40 \%$ of recent strawberry acreage in California (Hokanson and Finn, 2000). Initial planting stocks were certified nematode free by the California Department of Food and Agriculture. The planting stock used at Ballico LEN in both 2000 and 2001 and Susanville HEN was produced in MBPic fumigated soil at a commercial virusfree rearing facility.

Nursery study sites. Experiments were conducted at both low and high elevation commercial nurseries. Experimental plants grown at LEN were planting stock for the HEN and HEN plants were planting stock for fruit production fields. Following plants from LEN to HEN to fruit production fields allowed us to evaluate cumulative effects of runner plant production in soils fumigated with alternative chemicals.

Low-elevation nursery. The LEN was located near Ballico, Calif.(Lat. $37^{\circ} 4^{\prime} \mathrm{N}$, long. $120^{\circ} 5^{\prime} \mathrm{W}$ elevation about $120 \mathrm{~m})$. Two iterations of the LEN fumigation experiments were conducted, one in the 2000-01 season, and another in the 2001-02 season for which treatments were reapplied in the same locations (Table 1). The soil was a Tinnin loamy coarse sand (Sandy, mixed, thermic, Entic Haploxeroll) (sand 90\%, silt $7 \%$ ) with a $\mathrm{pH}$ of 7.4 and an organic matter content of $0.4 \%$. The previous crop was almond (Prunus dulcis L.). Liquid dairy manure was applied at $10 \mathrm{t} \cdot \mathrm{ha}^{-1}$ to the field before tillage operations. Conventional tillage practices were followed. Magnesium (35\% Mg), elemental sulfur $(90 \% \mathrm{~S})$, manganese sulfate $(28 \% \mathrm{Mn})$ and boron $(14.3 \% \mathrm{~B})$ were applied during final tillage operations at the rate of $168,84,224$, and $17 \mathrm{~kg} \cdot \mathrm{ha}^{-1}$, respectively, and preplant slow released granular fertilizer $(11 \mathrm{~N}-53 \mathrm{P}-50 \mathrm{~K})$ was applied at $420 \mathrm{~kg} \cdot \mathrm{ha}^{-1}$. Weather data collected during the production seasons at Ballico are presented in Table 1 .

High-elevation nurseries. The HEN experiments were conducted at two sites, the first was located near Susanville, Calif. (lat. $40^{\circ} 2^{\prime} \mathrm{N}$, long. $120^{\circ} 3^{\prime} \mathrm{W}$, elevation about 1200 $\mathrm{m})$, and the second was near Macdoel, Calif. (lat. $41^{\circ} 5^{\prime} \mathrm{N}$, long. $122^{\circ} \mathrm{W}$, elevation about 1294 $\mathrm{m})$. The Susanville evaluation was conducted in the 2000 season, and two experiments were conducted at Macdoel during the 2001 and 2002 seasons (Table 1). Soil at the Susanville site was classified as Fordney loamy fine sand (brown and dark grayish brown loamy fine sand) (sand $84 \%$, silt $10 \%$ ) with a pH of 7.6 and an organic matter content of $1.7 \%$. The Susanville HEN site had not been fumigated or used to grow strawberry previously. Preplant granular fertilizer (16N-20P-12K) was applied at 400 $\mathrm{kg} \cdot \mathrm{ha}^{-1}$ before planting. The soil at Macdoel was classified as Poman loamy sand (Sandy, mixed, mexic, Xerollic Durorthids) (sand 90\%, silt 6\%) with a $\mathrm{pH}$ of 6.0 and organic matter content of $0.6 \%$. The Macdoel 2001 site had been used previously for wheat (Triticum aestivum L.) and rye (Secale cereale L.) production, and had not been fumigated previously. The Macdoel 2002 site was previously used for strawberry runner plant production with a rye cover crop rotation and MBPic fumigation. Potassium oxide $(83 \% \mathrm{~K})$, gypsum $(23 \% \mathrm{Ca}, 19 \% \mathrm{~S})$ and elemental sulfur $(90 \% \mathrm{~S})$ were applied during land preparation at the rate of 224,120 , and

Table 1. Experimental locations, trial types (nursery or fruiting field), fumigation date, source of planting stock, planting date, harvest dates, precipitation and air temperature during each strawberry growing period.

\begin{tabular}{|c|c|c|c|c|c|c|c|c|c|}
\hline \multirow{2}{*}{$\begin{array}{l}\text { Trial } \\
\text { no. }\end{array}$} & \multirow[b]{2}{*}{ Location } & \multirow{2}{*}{$\begin{array}{l}\text { Trial } \\
\text { type }\end{array}$} & \multirow{2}{*}{$\begin{array}{l}\text { Fumigation } \\
\text { date }\end{array}$} & \multirow{2}{*}{$\begin{array}{l}\text { Plant } \\
\text { source }\end{array}$} & \multirow{2}{*}{$\begin{array}{l}\text { Planting } \\
\text { date }\end{array}$} & \multirow{2}{*}{$\begin{array}{l}\text { Harvest } \\
\text { dates }\end{array}$} & \multirow{2}{*}{$\begin{array}{l}\text { Precipitation }^{\mathrm{w}} \\
(\mathrm{mm})\end{array}$} & \multicolumn{2}{|c|}{ Temp ${ }^{\circ} \mathrm{C}^{\mathrm{v}}$} \\
\hline & & & & & & & & Min & Max \\
\hline$\overline{1}$ & Ballico & $\mathrm{LEN}^{\mathrm{z}}$ & 25 Apr. 2000 & MBPic stock & 12 May 2000 & 15 Jan. 2001 & 153 & 8.9 & 24.3 \\
\hline 2 & Ballico & LEN & 5 Apr. 2001 & MBPic stock & 5 May 2001 & 15 Jan. 2002 & 224 & 10.4 & 25.8 \\
\hline 3 & Susanville & $\mathrm{HEN}^{\mathrm{y}}$ & 4 Apr. 2000 & MBPic stock & 20 Apr. 2000 & 20 Oct. 2000 & 272 & 1.5 & 17.8 \\
\hline 4 & Macdoel & HEN & 26 Aug. 2000 & Ballico trial 1 & 20 Apr. 2001 & 2 Oct. 2001 & 59 & 4.5 & 26.0 \\
\hline 5 & Macdoel & HEN & 1 Aug. 2001 & Ballico trial 2 & 24 Apr. 2002 & 30 Sept. 2002 & 61 & 3.9 & 25.5 \\
\hline 6 & Watsonville & Fruit $^{\mathrm{x}}$ & 3 Oct. 2000 & Susanville trial 3 & 25 Oct. 2000 & 4 Apr. to 9 Aug. 2001 & 448 & 7.3 & 17.1 \\
\hline 7 & Watsonville & Fruit & 27 Sept. 2001 & Macdoel trial 4 & 26 Oct. 2001 & 19 Mar. to 7 Aug. 2002 & 433 & 6.9 & 16.1 \\
\hline 8 & Watsonville & Fruit & 2 Oct. 2002 & Macdoel trial 5 & 25 Oct. 2002 & 12 Mar. to 8 Sept. 2003 & 412 & 8.7 & 18.2 \\
\hline 9 & Oxnard & Fruit & 17 Aug. 2001 & Macdoel trial 4 & 8 Oct. 2001 & 5 Feb. to 24 June 2002 & 202 & 8.6 & 18.8 \\
\hline 10 & Oxnard & Fruit & 6 Sep. 2002 & Macdoel trial 5 & 7 Oct. 2002 & 31 Jan. to 17 June 2003 & 307 & 9.7 & 19.4 \\
\hline
\end{tabular}

${ }^{2}$ Low-elevation nursery (LEN) runner plant production.

${ }^{y}$ High-elevation nursery (HEN) runner plant production.

'Fruit field- strawberry fruit production.

"Precipitation $(\mathrm{mm})$ during strawberry growing seasons.

${ }^{v}$ Average air temperature (minimum and maximum ${ }^{\circ} \mathrm{C}$ ) during strawberry growing seasons. 
$560 \mathrm{~kg} \cdot \mathrm{ha}^{-1}$, and preplant granular fertilizer $(16 \mathrm{~N}-20 \mathrm{P}-0 \mathrm{~K})$ was applied at the rate of $560 \mathrm{~kg} \cdot \mathrm{ha}^{-1}$ before planting. Weather data for the Macdole and Susanville experiments are presented in Table 1 . The nursery experiments all utilized sprinkler irrigation.

Nursery study design. A randomized complete block design with four replications was used for all nursery experiments. At Ballico, treatments were 1) MBPic (57\% MB: $43 \%$ Pic), applied at $\left.450 \mathrm{~kg} \cdot \mathrm{ha}^{-1} ; 2\right)$ IMPic $(50 \%$ IM: $50 \%$ Pic), applied at $392 \mathrm{~kg} \cdot \mathrm{ha}^{-1}$, and 3 ) nonfumigated control(NF). Plots measured 10 $\times 46 \mathrm{~m}$ and mother plant spacing was $100 \mathrm{~cm}$ between rows and $90 \mathrm{~cm}$ between plants within each row. Planting and harvest dates at Ballico were 12 May 2000 and 15 Jan. 2001 (season one) and 5 May 2001 and 15 Jan. 2002 (season two). Runner plants were harvested by machine from a $1 \times 15 \mathrm{~m}$ area near the center of each plot. After harvest trained crews provided by the cooperating grower sorted the runner plants into marketable (i.e., those plants that appeared likely to grow vigorously after transplanting) and nonmarketable classes, then trimmed and counted the plants. Marketable plants were placed in cold storage until transfer to Macdoel for HEN daughter runner plant production, and unmarketable plants were discarded.

At the Susanville HEN, the treatments were 1) MBPic (67\% MB: 33\% Pic) $\left.400 \mathrm{~kg} \cdot \mathrm{ha}^{-1}, 2\right)$ IMPic (50\% IM: 50\% Pic) $392 \mathrm{~kg} \cdot \mathrm{ha}^{-1}$ and 3 ) NF. Mother plant spacing was $100 \mathrm{~cm}$ between rows and in-row plant spacing was $30 \mathrm{~cm}$. The plots were $6.7 \times 40 \mathrm{~m}$ with 6 rows per plot. Planting and harvest dates were 20 Apr. 2000 and 20 Oct. 2000, respectively. Daughter runner plants were harvested and sorted as described previously. After cold storage $\left(4{ }^{\circ} \mathrm{C}\right)$ these plants were transplanted into a fruiting field at Watsonville, Calif.

At the Macdoel HEN the treatments in the 2001 and 2002 seasons were 1) MBPic (57\% MB: $43 \%$ Pic) $\left.450 \mathrm{~kg} \cdot \mathrm{ha}^{-1}, 2\right)$ IMPic (50\% IM: $50 \%$ Pic) $\left.392 \mathrm{~kg} \cdot \mathrm{ha}^{-1}, 3\right) 61 \% 1,3$-D plus $35 \%$ Pic (Telone C35) mixture $300 \mathrm{~L} \cdot \mathrm{ha}^{-1}$ followed by (fb) DZ $280 \mathrm{~kg} \cdot \mathrm{ha}^{-1}$, 4) Pic $336 \mathrm{~kg} \cdot \mathrm{ha}^{-1} \mathrm{fb}$ DZ $280 \mathrm{~kg} \cdot \mathrm{ha}^{-1}$, and 5) NF. For both seasons, mother plant spacing was $91 \mathrm{~cm}$ between rows and $46 \mathrm{~cm}$ within rows. All plots were $10 \times 45$ $\mathrm{m}$, there were 8 rows per plot, and each plot was divided length-wise into three $10 \times 15 \mathrm{~m}$ subplots. Marketable runner plants from each of the three treatments at Ballico were randomly assigned and planted as mother plants in each subplot. Hence each plot at Macdoel had plants from all three Ballico treatments. Planting and harvest dates for season one at Macdoel were 20 Apr. 2001 and 2 Oct. 2001, respectively, and for season two, they were 24 Apr. 2002 and 30 Sept. 2002, respectively.

Nursery fumigant application. Standard methods for broadcast fumigation were utilized at all nursery locations. Fumigants were shank injected before planting and the soil was covered with polyethylene tarp as the fumigant was applied. In 2000 at Ballico fumigants were shank injected on 25 Apr. 2000 to a depth of about $30 \mathrm{~cm}$ with six chisels spaced $35 \mathrm{~cm}$ apart when soil temperature (15 to $45 \mathrm{~cm}$ depth) was 17 to $18^{\circ} \mathrm{C}$. Soil was immediately covered with black high-density polyethylene $\operatorname{tarp}(28 \mu \mathrm{m}$ thickness). On 1 May 2000 the tarp was removed. Similarly, in 2001, fumigants were shank injected on 5 Apr. 2001 when soil temperature (15 to $45 \mathrm{~cm}$ depth) was 17 to 18 ${ }^{\circ} \mathrm{C}$ and the tarp was removed on 10 Apr. 2001. At Susanville, fumigants were shank injected on 4 Apr. 2000, when soil temperature (at 15 to $45 \mathrm{~cm}$ depth) was 12 to $14{ }^{\circ} \mathrm{C}$ and the clear polyethylene tarp was removed on $10 \mathrm{Apr}$ 2000. At Macdoel, MBPic, IMPic, Pic and Telone C35 were shank injected on 26 Aug. 2000 (soil temperature 16 to $20^{\circ} \mathrm{C}$ at 15 to 45 $\mathrm{cm}$ ) for 2001 runner plant production and on 1 Aug. 2001 for 2002 runner plant production. The tarp was removed on 9 Sept. 2000 for the 2001 season and on 7 Aug. 2001 for the 2002 season. For both seasons, DZ was applied to the soil surface of the appropriate plots with a granular spreader the day after tarp removal and activated in the soil by sprinkler irrigation according to label directions (BASF, 1997). With the rates used, the DZ treatment was intended primarily for weed control.

Fruit production studies. Strawberry fruit production experiments were conducted in commercial fields on the central and south coast of California. On the south coast near Oxnard (lat. $33^{\circ} 1$ 'N, long. $119^{\circ} 1^{\prime} \mathrm{W}$, elevation $14.59 \mathrm{~m}$ ) experiments were located at Martinez Berry Farm (2001-02) and at Sea Crest Farm (2002-03). On the central coast near Watsonville (lat. $36^{\circ} 5^{\prime} \mathrm{N}$, long. $121^{\circ} 5^{\prime} \mathrm{W}$, elevation $64.45 \mathrm{~m}$ ) experiments were located at the Monterey Bay Academy and farmed by Coastal Berry. The soil at the Oxnard site was classified as a Hueneme sandy loam (coarseloamy, mixed, calcarius, thermic, Cumulic Haploxeroll) with $60 \%$ sand, $28 \%$ silt, a pH of 7.8 and organic matter content of $0.7 \%$. The soil at Watsonville was classified as an Elder sandy loam (coarse-loamy, mixed, thermic, Cumulic Haploxeroll) with $62 \%$ sand, $26 \%$ silt, a pH of 6.1 and organic matter content of $0.6 \%$. Weather data for each production season at Oxnard and Watsonville are presented in Table 1. Standard cultural practices for commercial production were followed (CSC, 1999). At Watsonville raised beds measured $130 \mathrm{~cm}$ (center-to-center) and strawberries were planted with two rows per bed spaced $40 \mathrm{~cm}$ apart. At Oxnard, bed spacing was 170 $\mathrm{cm}$ center-to-center with four rows of plants per bed spaced $28 \mathrm{~cm}$ apart. In both locations plant-to-plant spacing within each row was $35 \mathrm{~cm}$. Slow release fertilizer $(18 \mathrm{~N}-8 \mathrm{P}-13 \mathrm{~K})$ was applied at the rate of $672 \mathrm{~kg} \cdot \mathrm{ha}^{-1}$ at Watsonville and $896 \mathrm{~kg} \cdot \mathrm{ha}^{-1}$ at Oxnard. Fertilizer was applied in a band placed about $15 \mathrm{~cm}$ deep in the planting slot and covered with about $4 \mathrm{~cm}$ soil to prevent direct contact with the new transplants. A drip irrigation system was installed consisting of two drip tapes (Netafilm Streamline 60; Netafilm, Fresno, Calif.) buried 2 to $4 \mathrm{~cm}$ deep with emitters spaced $30 \mathrm{~cm}$ apart with an emitter flow rate of $0.87 \mathrm{~L} \cdot \mathrm{min}^{-1}$ at $70 \mathrm{kPa}$, placed $8 \mathrm{~cm}$ (Watsonville) or $30 \mathrm{~cm}$ (Oxnard) from bed center. Runner plants raised at Susanville in 2000 were transplanted to the Watsonville site on 25 Oct. 2000. Runner plants raised at Macdoel were transplanted at the
Oxnard site on 8 Oct. 2001 and 7 Oct. 2002, and at Watsonville site on 26 Oct. 2001 and on 25 Oct. 2002 (Table 1). Sprinkler irrigation (about $25 \mathrm{~mm}$ per week) was used for four weeks during plant establishment. After plant establishment, drip-irrigation was applied once or twice a week for 1.5 to $2 \mathrm{~h}$ depending on soil moisture conditions. Hand weeding was done as necessary. Cooperating growers determined when weeding was necessary.

Fruit field study design. Experiments were conducted in fruit production fields at Watsonville for three seasons $(2000-01,2001-02$, and 2002-03) and at Oxnard for two seasons (2001-02 and 2002-03) (Table 1). The fruit field experiments used a split-plot design arranged in a randomized complete block with four replications. The two main plots were fumigated with 1) MBPic or 2) Pic. Runner plants from Macdoel with different soil fumigation histories were planted in each of the main plots at the fruit field (i.e., nursery fumigant history was the subplot). The MBPic and Pic main plots in the 2000-01 experiment in Watsonville were each planted with marketable runner plants from each of the three fumigation treatments at the Susanville HEN. Similarly, the MBPic and Pic main plots in the 2001-02 and 2002-03 experiments at Watsonville and Oxnard received runner plants from each of the five fumigation regimes at the Macdoel HEN. Because of space and resource limitations it was not possible to carry forward to the fruiting field all combinations of LEN and HEN soil treatments. Plants with the following Ballico LEN-to-Macdoel HEN fumigant histories were evaluated in fruit production trials: NF-to-NF, MBPic-to-MBPic, IMPic-to-IMPic, MBPicto-Pic fb DZ and MBPic-to-Telone C35 fb DZ. Subplots in the fruiting field were 1 bed wide $\times 532 \mathrm{~cm}$ long with 2 rows per bed at Watsonville and 1 bed wide $\times 353 \mathrm{~cm}$ long with 4 rows per bed at Oxnard. For each subplot, 30 plants were used to measure strawberry yield at Watsonville and 40 plants were used at Oxnard. Each week during harvest season, commercial harvest personnel provided by the cooperating grower, harvested, sorted and weighed marketable and cull fruit (Table 1). The harvest crews were trained by the grower to grade marketable and cull fruit.

Fruit field fumigant application. Raised beds were fumigated in fruit fields at Oxnard during the 2001-02 and 2002-03 seasons. The fumigants MBPic [ $(57 \% \mathrm{MB}: 43 \% \mathrm{Pic})$ applied at $392 \mathrm{~kg} \cdot \mathrm{ha}^{-1}$ of treated area] and Pic (224 $\mathrm{kg} \cdot \mathrm{ha}^{-1}$ treated area, only in 2001-02) were injected to a depth of 15 to $25 \mathrm{~cm}$ through two hollow shanks. The soil was covered with clear polyethylene tarp following fumigant application. Soil temperatures at 15 to $30 \mathrm{~cm}$ were 18 to $24{ }^{\circ} \mathrm{C}$ at the time of fumigation. In the 2002-03 season, Pic only was applied through the drip irrigation system as described by Ajwa etal.(2002). At Watsonville, broadcast fumigation was performed each year before bed formation. Fumigants MBPic (57\% MB:43\% Pic) and Pic were injected at 15 to $25 \mathrm{~cm}$ below the soil surface through hollow shanks followed immediately by covering with a clear polyethylene tarp. These tarps were removed 
after several days; beds were then formed and covered with black or brown high-density polyethylene tarp (35.6 $\mu \mathrm{m}$ thickness).

Statistical analyses. Data were analyzed using the SAS general linear model (GLM) procedure (SAS Institute, Cary, N.C.). Runner plant production at Ballico and Susanville was analyzed for fumigation treatment effects using ANOVA. Runner plant production data from Macdoel were analyzed to evaluate the effects of Ballico fumigants and their interaction (Macdoel nested within Ballico). Fruiting field data were nested according to the previous Macdoel fumigation treatments but were not further nested by the Ballico fumigation treatments because some of the possible treatment combinations were not evaluated. After testing for normality, data were $\log$ or arc sin transformed as necessary for statistical analysis. Data were converted to original units for presentation in the tables. Single degree-of-freedom orthogonal contrasts also were used to make comparisons between specific treatments.

\section{Results}

Runnerplantproduction. At the Ballico LEN in 2000 and 2001 total and marketable runner yields were greater in fumigated than NF soil, and the effects of MBPic and IMPic on runner production did not differ $(P=0.05$, Table 2$)$. While runner plant yields at the Susanville HEN with the IMPic and MBPic soil treatments did not differ $(P>0.05)$, only the MBPic yields significantly exceeded NF yields (Table 2 ).

At Macdoel in 2001, runner plant production was higher in all of the fumigated treatments than in the NF treatment (Table 3). Ballico LEN fumigation did not effect the number of marketable plants produced at Macdoel HEN in $2001(P=0.09$, Table 3). However, the ANOVA indicated that the total number of plants produced was significantly greater $(P=0.03)$ in plots where the source of the planting stock was Ballico LEN 2000 IMPic or MBPic compared to Ballico NF stock (data not shown). The number of marketable runner plants produced at Macdoel in 2001 for the MBPic-to-MBPic sequence was $1.2 \times 10^{6} /$ ha compared to $7.7 \times$ $10^{5}$ /ha for the NF-to-NF sequence (significantly different, $P=0.01$ ). Single degree-of-freedom contrasts indicated that runner plant numbers for the MBPic-to-MBPic (Ballico-to-Macdoel) fumigation sequence were higher than for plants with the MBPic-to-NF and IMPic-to-NF (Ballico-to-Macdoel) fumigant histories (data not shown). In other words there were significant carry over effects of no fumigation compared to MBPic fumigation in LEN on runner production at HEN.

Comparisons among all fumigation treatments indicated that local fumigation at Macdoel in 2002 with Pic fb DZ resulted in more marketable runner plants than other treatments, including MBPic $(P \leq 0.05)$. However, in total runner plant production MBPic had a yield similar to all the other fumigation treatments (Table 3). Effects from the Ballico LEN 2001 fumigant treatment history were not detected in the runner plant yield data from 2002 Macdoel HEN. The number of marketable runner plants produced

Table 2. Marketable and total strawberry runner plant production at Ballico in 2000-01 and 2001-02, and at Susanville in 2000.

\begin{tabular}{|c|c|c|c|c|c|c|}
\hline \multirow[b]{3}{*}{ Fumigant ${ }^{z}$} & \multicolumn{6}{|c|}{$\begin{array}{c}\text { Production } \\
(1,000 \text { runner plants/ha) }\end{array}$} \\
\hline & \multicolumn{2}{|c|}{ Ballico 2000-01 } & \multicolumn{2}{|c|}{ Ballico 2001-02 } & \multicolumn{2}{|c|}{ Susanville 2000} \\
\hline & Marketable $^{y}$ & Total & Marketable & Total & Marketable & Total \\
\hline MBPic & $1,742 \mathrm{a}$ & $2,416 a$ & $2,599 \mathrm{a}$ & $3,541 \mathrm{a}$ & $825 \mathrm{a}$ & $1,428 \mathrm{a}$ \\
\hline IMPic & $1,547 \mathrm{a}$ & $2,422 \mathrm{a}$ & $2,440 \mathrm{a}$ & $3,418 \mathrm{a}$ & $670 a b$ & $1,182 \mathrm{ab}$ \\
\hline NF & $723 \mathrm{~b}$ & $1,289 \mathrm{~b}$ & $1,838 \mathrm{~b}$ & $2,516 \mathrm{~b}$ & $368 \mathrm{~b}$ & $659 \mathrm{~b}$ \\
\hline
\end{tabular}

${ }^{2}$ Abbreviations: MBPic $=$ methyl bromide plus chloropicrin; IMPic $=$ iodomethane plus chloropicrin; $\mathrm{NF}$ $=$ nonfumigated control.

${ }^{y}$ Means sharing the same letters within a column are not different according to the Duncan's multiple range test $(P=0.05)$.

Table 3. Marketable and total strawberry runner plant production at Macdoel in 2001 and 2002.

\begin{tabular}{|c|c|c|c|c|}
\hline \multirow[b]{3}{*}{ Fumigant $^{2, y}$} & \multicolumn{4}{|c|}{$\begin{array}{c}\text { Production } \\
(1,000 \text { runner plants/ha) }\end{array}$} \\
\hline & \multicolumn{2}{|c|}{ Marketable plants } & \multicolumn{2}{|c|}{ Total plants } \\
\hline & $2001^{x}$ & 2002 & 2001 & 2002 \\
\hline MBPic & $1,183 \mathrm{a}$ & $883 \mathrm{~b}$ & $2,105 \mathrm{a}$ & $1,345 \mathrm{ab}$ \\
\hline IMPic & $1,202 \mathrm{a}$ & $820 \mathrm{~b}$ & $2,078 \mathrm{a}$ & $1,198 \mathrm{bc}$ \\
\hline Pic fb DZ & $1,164 \mathrm{a}$ & $1,027 \mathrm{a}$ & $2,050 \mathrm{a}$ & $1,421 \mathrm{a}$ \\
\hline Telone C35 fb DZ & $1,117 \mathrm{a}$ & $806 \mathrm{~b}$ & $2,048 \mathrm{a}$ & $1,198 \mathrm{bc}$ \\
\hline NF & $879 \mathrm{~b}$ & $769 \mathrm{~b}$ & $1,591 \mathrm{~b}$ & $1,088 \mathrm{c}$ \\
\hline
\end{tabular}

${ }^{2}$ The effects of Macdoel fumigants are presented alone as the carryover effects of Ballico fumigants on source plants were not significant for $2001(P=0.09)$ or $2002(P=0.27)$.

${ }^{y}$ Abbreviations: $\mathrm{MBPic}=$ methyl bromide plus chloropicrin; IMPic $=$ iodomethane plus chloropicrin; Pic $\mathrm{fb} \mathrm{DZ}=$ chloropicrin followed by dazomet; Telone $\mathrm{C} 35 \mathrm{fb} \mathrm{DZ}=$ Telone $\mathrm{C} 35$ followed by dazomet; $\mathrm{NF}=$ nonfumigated control.

${ }^{x}$ Means sharing the same letters within a column are not different according to the Duncan's multiple range test $(P=0.05)$.

at Macdoel in 2002 for the MBPic-to-MBPic sequence was $9.1 \times 10^{5} /$ hacompared to $6.5 \times$ $10^{5} /$ ha for the NF-to-NF sequence (significantly different, $P=0.02)$. In addition, plants with an IMPic-to-IMPic history had significantly $(P \leq$ $0.05)$ lower total runner plant production than plants with a MBPic-to-MBPic history. The use of MBPic-to-Pic fb DZ (Ballico-to-Macdoel) fumigant sequence increased total and marketable runner plant production by $21 \%$ to $32 \%$ compared to the standard MBPic-to-MBPic sequence.

Fruit production. Fruit yield data are presented as cumulative seasonal yield per strawberry plant for each location and year. In 2000-01, the effect of the local fumigant was significant $(P \leq 0.01)$ at Watsonville, and cumulative strawberry yields were greater in the Pic fumigated plots than in MBPic fumigated plots (marketable and total yields increased 7\% and 5\%, respectively, Table 4). Surprisingly, the HEN-to-fruiting field treatment NF-to-Pic had higher marketable and total yields than the MBPic-to-MBPic treatment (Table 4). The ANOVA indicated that main effects of Susanville HEN source fumigants on marketable and total fruit yields were significant $(P=0.02$ and 0.01 , respectively). This suggests there was a carryover effect of nursery fumigation treatment on fruit yield at Watsonville.

In 2001-02, the effect of the local fumigant at Watsonville was significant $(P \leq 0.01)$, and overall fruit yield was greater in plots fumigated with MBPic than with Pic (Table 5). When the Macdoel-to-Watsonville fumigation sequence was Pic fb DZ-to-MBPic fruit yields were significantly higher $(P=0.03)$ than with the standard MBPic-to-MBPic sequence (Table 5). However, there was no difference in fruit production on Pic-fumigated soil between the
Pic fb DZ and MBPic nursery plants. Plants with Macdoel-to-Watsonville fumigation sequences of IMPic-to-Pic, MBPic-to-Pic or NF-to-Pic produced less fruit than MBPic-toMBPic plants.

In 2002-03 at Watsonville, marketable fruit yields on soils fumigated with Pic were larger than those on soils fumigated with MBPic (Table $5)$. This contrasts with the previous season (2001-02), when marketable yield was significantly $(P \leq 0.01)$ greater in plots fumigated with MBPic than Pic. When the fumigant application sequence from Macdoel-to-Watsonville was IMPic-to-MBPic or IMPic-to-Pic, total fruit yield was significantly lower than when the

Table 4. Marketable and total strawberry fruit yields at Watsonville in 2000-01 from runner plants produced at Susanville in 2000 .

\begin{tabular}{|c|c|c|c|}
\hline \multicolumn{2}{|c|}{ Fumigant } & \multicolumn{2}{|c|}{$\begin{array}{c}\text { Yield } \\
\text { (g/plant) }\end{array}$} \\
\hline Susanville ${ }^{z, y}$ & $\overline{\text { Watsonville }}$ & Marketable $^{x}$ & Total \\
\hline$\overline{\text { MBPic }}$ & MBPic & $1329.8 \mathrm{bc}$ & $1946.8 \mathrm{~b}$ \\
\hline IMPic & MBPic & $1318.2 \mathrm{c}$ & $1919.9 \mathrm{~b}$ \\
\hline NF & MBPic & $1385.9 \mathrm{bc}$ & $2025.6 \mathrm{~b}$ \\
\hline MBPic & Pic & $1436.2 \mathrm{ab}$ & $2055.2 \mathrm{ab}$ \\
\hline IMPic & Pic & $1386.9 \mathrm{bc}$ & $2001.6 b$ \\
\hline NF & Pic & $1525.7 \mathrm{a}$ & $2171.6 \mathrm{a}$ \\
\hline
\end{tabular}

${ }^{\text {zSusanville column indicates the fumigant used for }}$ runner plant production at the high elevation nursery in 2000 and the Watsonville column indicates the fumigant at the fruiting field for 2001. The effects of the Susanville fumigants on marketable fruit yields were significant $(P=0.02)$, as were the effects of fumigant treatments in Watsonville $(P \leq 0.01)$. ${ }^{y}$ Abbreviations: $\mathrm{MBPic}=$ methyl bromide plus chloropicrin; IMPic = iodomethane plus chloropicrin; Pic $=$ chloropicrin; $\mathrm{NF}=$ nonfumigated, control.

${ }^{\mathrm{x}}$ Means sharing the same letters within a column are not different according to the Duncan's multiple range test $(P=0.05)$. 
Table 5. Marketable and total strawberry fruit yields at Watsonville in 2001-02 and 2002-03 from runner plants produced at Macdoel in 2001 and 2002, respectively.

\begin{tabular}{|c|c|c|c|c|c|}
\hline & & \multicolumn{4}{|c|}{$\begin{array}{c}\text { Yield } \\
\text { (g/plant) }\end{array}$} \\
\hline \multicolumn{2}{|c|}{ Fumigant } & \multicolumn{2}{|c|}{ Marketable fruit } & \multicolumn{2}{|c|}{ Total fruit } \\
\hline Macdoel $^{z, y}$ & Watsonville & $2001-02^{x}$ & $2002-03$ & $2001-02$ & $2002-03$ \\
\hline MBPic & MBPic & $1474.0 \mathrm{bc}$ & $1226.8 \mathrm{def}$ & $2070.3 \mathrm{abc}$ & $2600.6 \mathrm{ab}$ \\
\hline IMPic & MBPic & $1526.8 \mathrm{ab}$ & $1137.3 \mathrm{f}$ & $2151.8 \mathrm{ab}$ & $2399.8 \mathrm{~cd}$ \\
\hline Pic fb DZ & MBPic & $1634.5 \mathrm{a}$ & $1265.8 \mathrm{cde}$ & $2275.1 \mathrm{a}$ & $2707.3 \mathrm{a}$ \\
\hline Telone C35 fb DZ & MBPic & $1434.1 \mathrm{bcd}$ & 1208.3 ef & $2068.1 \mathrm{abc}$ & $2567.8 \mathrm{ab}$ \\
\hline $\mathrm{NF}$ & MBPic & $1520.3 \mathrm{ab}$ & $1276.9 \mathrm{cde}$ & $2120.4 \mathrm{ab}$ & $2677.3 \mathrm{ab}$ \\
\hline MBPic & Pic & $1235.8 \mathrm{e}$ & $1330.3 \mathrm{bc}$ & $1786.6 \mathrm{~d}$ & $2551.1 \mathrm{ab}$ \\
\hline IMPic & Pic & 1278.2 de & $1245.7 \mathrm{cde}$ & $1803.3 \mathrm{~d}$ & $2372.5 \mathrm{~d}$ \\
\hline Pic fb DZ & Pic & 1388.4 bcde & $1422.3 \mathrm{a}$ & $1963.4 \mathrm{bcd}$ & $2632.4 \mathrm{ab}$ \\
\hline Telone C35 fb DZ & Pic & 1346.4 cde & $1308.2 \mathrm{bcd}$ & $1899.7 \mathrm{~cd}$ & $2528.9 \mathrm{bc}$ \\
\hline $\mathrm{NF}$ & Pic & $1301.7 \mathrm{de}$ & $1371.9 \mathrm{ab}$ & $1837.3 \mathrm{~d}$ & $2628.9 \mathrm{ab}$ \\
\hline
\end{tabular}

${ }^{2}$ Macdoel column indicates the fumigant used for runner plant production at the high elevation nursery in 2001 or 2002 and the Watsonville column indicates the fumigant at the fruiting field for 2001-02 and 2002-03 seasons. The effect of the Macdoel fumigant on marketable fruit yield at Watsonville was significant in 2001-02 $(P=0.04)$ and 2002-03 $(P \leq 0.01)$ as was the effect of Watsonville fumigation treatment on total yield $(P<0.01)$ for both $2001-02$ and $2002-03$.

${ }^{y}$ Abbreviations: MBPic $=$ methyl bromide plus chloropicrin; $\mathrm{IMPic}=$ iodomethane plus chloropicrin; Pic $\mathrm{fb} \mathrm{DZ}=$ chloropicrin followed by dazomet; Telone $\mathrm{C} 35 \mathrm{fb} \mathrm{DZ}=$ Telone $\mathrm{C} 35$ followed by dazomet; $\mathrm{NF}=$ nonfumigated control.

${ }^{x}$ Means sharing the same letters within a column are not different according to the Duncan's multiple range test $(P=0.05)$.

Table 6. Marketable and total strawberry fruit yields at Oxnard in 2001-02 and 2002-03 from runner plants produced at Macdoel in 2001 and 2002, respectively.

\begin{tabular}{lccccc}
\hline & \multicolumn{3}{c}{ Yield (g/plant) } \\
\cline { 2 - 3 } \cline { 5 - 6 } Oxnard ${ }^{z, y}$ & \multicolumn{2}{c}{ Marketable fruit } & & \multicolumn{2}{c}{ Total fruit } \\
\cline { 2 - 3 } fumigant & $2001-02^{\mathrm{x}}$ & $2002-03$ & & $2001-02$ & $1481.3 \mathrm{a}$ \\
\hline MBPic & $578.5 \mathrm{a}$ & $1201.9 \mathrm{a}$ & & $671.4 \mathrm{a}$ & $1449.8 \mathrm{a}$ \\
Pic & $527.0 \mathrm{~b}$ & $1181.9 \mathrm{a}$ & & $623.2 \mathrm{~b}$ & 1
\end{tabular}

${ }^{\mathrm{z}}$ Oxnard column indicates the fumigant used at the fruiting field in the 2001-02 and 2002-03 seasons. The effects of fumigant used to produce the source plants at Macdoel on fruit production were not significant $(P=0.05)$ for either production season.

${ }^{\mathrm{y}}$ Abbreviations: same as Table 5.

${ }^{x}$ Means sharing the same letters within a column are not different according to the Duncan's multiple range test $(P=0.05)$.

fumigation sequence was MBPic-to-MBPic, but these differences were not observed for marketable yield. Some of the Macdoel HEN fumigant treatments had significant $(P \leq 0.01)$ carryover effects on fruit yields at Watsonville in the 2002-03 season.

The effect of the Macdoel source fumigants on fruit yield at Oxnard was not significant for either the 2001-02 or 2002-03 season (Table 6), indicating that there was no carry over effect of Macdoel fumigation on Oxnard fruit production. Marketable and total fruit yields in 2001-02 were significantly $(P \leq 0.01)$ greater where MBPic was used as the local fumigant rather than Pic. However, in 2002-03 both fumigants had similar effects on fruit yield. At Oxnard, overall fruit yield was lower in 2001-02 than 2002-03. An infestation of Colletotrichum acutatum at the Oxnard field site in 2001-02 may have contributed to the lower yields compared to the 2002-03 season.

\section{Discussion}

Potential for the alternatives to replace MBPic. Our results suggest that IMPic, Pic $\mathrm{fb}$ DZ, and Telone C35 fb DZ, are potential alternative fumigants for strawberry nurseries. Although we did not evaluate Pic as a potential LEN fumigant, Larson and Shaw (2000) found overall that runner plant production in LEN and HEN with MBPic was greater than were comparable to HEN plants produced on MBPic fumigated soils.

We did not observe differences in fruit production by plants that were propagated at high elevation nurseries on nonfumigated or MBPic fumigated soils (Tables 4 and 5). This is perhaps surprising because we found reduced runner plant numbers where plants were grown without fumigation in two cycles of propagation at low and high elevation nurseries compared to numbers of runner plants produced on MBPic fumigated soils. A possible explanation is that the history of fumigant use in nursery propagation has less effect on fruit yields than the fumigant finally used for fruit production (Larson, 1997). Larson and Shaw (2000) found in comparisons of MBPic and NF in strawberry nurseries that the fumigant used in the last propagation cycle had a larger effect than did the fumigant used in the previous propagation cycle. In other words the effect of the local fumigant was more important than the fumigant history of the plant. Another possibility is that the three HEN sites were reinfested with sublethal pathogens after fumigation and/or by transplanting, such that some disease pressure in fumigated plots reduced differences between treatments. For example, $>65 \%$ of the plants harvested from all treatments at Susanville were infested with Pythium spp. and $>47 \%$ were infested with Rhizoctonia spp. (F. Martin, unpublished results). A more detailed analysis of pathogen colonization of the planting material is in progress and will be reported elsewhere. Another factor that may minimize the differences between treatments could be plant sorting. In the process of sorting, weak and poorly formed plants were culled, thus most plants selected for transplanting were healthy looking. This research was conducted at typical strawberry nursery sites, using typical production practices. Cultural practices such as crop rotation, use of cover crops and fallow periods also likely contributed to reduced incidence of soilborne diseases at these sites. Reduced levels of pathogens in NF treatments due to cultural practices would also contribute towards reduced differences in plant yields between treatments by minimizing the chance of encountering severe soil pathogen levels.

Many factors need consideration before one can conclude that IMPic, Pic fb DZ and Telone $\mathrm{C} 35 \mathrm{fb} \mathrm{DZ}$ are viable alternative fumigant treatments for California strawberry nurseries. Foremost is that current nursery fumigation practices are partly a response to regulatory oversight for nursery stock certification by the California Dept. of Food and Agriculture to ensure that plants are free of nematodes. Methyl bromide and Telone II are currently the only soil treatments approved for nursery field production of certified materials (CDFA 2002). If alternative fumigants are to replace $\mathrm{MB}$, they must reproduce the high nursery sanitation standards that have been obtained with $\mathrm{MB}$, as well as have the consistency and dependability of the MBPic that nursery producers now use to propagate high quality plants (USDS, 2003). Many more tests than were conducted here or elsewhere (e.g., DeCal et al., 2004a, 2004b; Larson and Shaw, 2000) 
will be required to verify that one or more of the alternative fumigant treatments tested here will perform as consistently as MBPic under high pest pressure.

We found inconsistency in Pic performance in fruit production fields. Chloropicrin fumigated soils yielded more marketable fruit than MBPic at Watsonville in 2001 and 2003 (Tables 4 and 5) but yielded less than MBPic in 2002 at Watsonville, and Oxnard (Tables 5 and 6); no differences were observed at Oxnard in 2003 (Table 6). Shaw and Larson (1999) observed that soil fumigation with shank applied Pic in place of MBPic resulted in $6.8 \%$ fruit yield loss at rates 336 to $396 \mathrm{~kg} \cdot \mathrm{ha}^{-1}$ and $15.4 \%$ yield loss at rates 168 to $224 \mathrm{~kg} \cdot \mathrm{ha}^{-1}$ in California. However, use of drip applied Pic, or 1,3-D plus Pic (Inline) followed by metam sodium provided fruit yields that were comparable to MBPic (Ajwa and Trout 2004).

Registration status of alternative fumigants. Chloropicrin and Telone $\mathrm{C} 35$ are registered for all uses described in this research (CDMS, 2004; CPR, 2004). California limitations on the total amount of 1,3-D (Telone C 35 component) that can be used each season per township $\left(93 \mathrm{~km}^{2}\right)$ may restrict the use of Telone C35 as a replacement for MBPic in strawberry fruit production districts (Carpenter et al., 2001). However, in California counties where strawberry nursery production occurs, such as Stanislaus (Ballico) and Siskiyou (Macdoel), current California regulations are not predicted to limit the use of Telone C35. Dazomet is registered for use on nonbearing strawberry, provided fruit harvest does not occur within one year of application (BASF, 1997). The timing of DZ application in August or September at the HEN nursery followed by plant harvest and transplanting to fruit production fields during September to November of the following year is in compliance with the DZ label. While we did not test DZ at the LEN, its use there would be in compliance with the label. An application for IM registration was submitted to the U.S. EPA in early 2002 (Martin, 2003), however, decisions on Federal and California registrations are still pending (Allen, 2003; Neil Phillips, Arvesta Corporation, personal communication).

Difficulties with implementation of alternative fumigants. Our results suggest that IMPic is a possible replacement for MBPic at both the LEN and HEN runner plant nurseries. However, at this time the cost of IM is unknown and the economic viability of this product as a strawberry nursery fumigant remains to be determined. The use of a sequential application of DZ following either Telone C35 or Pic, involves two applications, and we assume a higher application cost than the single application necessary for IMPic or MBPic. Furthermore, DZ is a fine grade material that drifts readily and conditions at the HEN at the time of application in late summer were windy, which made it difficult to apply DZ evenly. Also, DZ breakdown products, including MITC, are more effective against pests and weeds when the soil is tarped after application (Eitel, 1995; Park and Landschoot, 2003). In the Macdoel studies, the soil was tarped for the preceding fumigant applications but tarps were removed before the DZ application; had the soil been retarped the efficacy of DZ may have been increased. The cost of nursery production with the alternative fumigants, including fumigant application costs, will be considered in a separate publication.

Conclusion. The alternative fumigants evaluated here may have potential as replacements for MB in the runner plant nurseries. The sequential application of Pic $\left(336 \mathrm{~kg} \cdot \mathrm{ha}^{-1}\right)$ or Telone C35 $\left(300 \mathrm{~L} \cdot \mathrm{ha}^{-1}\right)$ for pathogen control followed by DZ (280 kg.ha-1) for weed control in the nurseries resulted in runner plant production equivalent to the standard MBPic treatment. The mixture of IM and Pic (50:50) resulted in plant yields in the LEN and HEN that were similar to MBPic. The IMPic, Pic fb DZ and Telone C35 fb DZ treatments all provided runner plants of sufficient quality and vigor to support fruit yield in commercial fruit production fields equivalent to the standard MBPic nursery fumigation treatment. The greater production of nursery plants at the HEN following treatments with Pic fb DZ in one out of two seasons is intriguing and warrants further investigation.

As part of the studies reported here, data were collected on the efficacy of fumigation treatments on survival of several plant pathogens, weeds and nematodes in the soil, the colonization frequencies of nursery plants by the pathogens and nematodes, and the economic viability of the various fumigation treatments. While those results will be reported elsewhere, the results for plant production reported here indicate further research on all fumigant treatments used is warranted to evaluate their applicability as replacements for MB in the strawberry nursery and fruit production systems. This would include evaluating consistency of pest management after successive years of application, rate studies and improved application technology to enhance the efficacy of pest control, inclusion of additional geographically diverse study sites to evaluate treatment efficacy on fruit production, as well as an economic analysis of the feasibility of integrating these potential alternatives into strawberry production systems. Before any of these alternative fumigation treatments can replace $\mathrm{MB}$ as the standard nursery treatment for plant certification at the state level, more intensive trials to evaluate pest survival will be needed.

\section{Literature Cited}

Ajwa H.A. and T. Trout. 2004. Drip application of alternative fumigants to methyl bromide for strawberry production. HortScience 39:1707-1715.

Ajwa H.A., T. Trout, J. Mueller, S. Wilhelm, S.D. Nelson, R. Soppe, and D. Shatley. 2002. Application of alternative fumigants through drip irrigation systems. Phytopathology 92:1349-1355.

Allen, M.A. 2003. Midas soil fumigant, registration and development update. Annu. Intl. Res. Conf. Methyl Bromide Alternatives and Emissions Reductions. Abstr. 24.

Anbar, A.D., Y.L. Young, and F.P. Chavez. 1996. Methyl bromide: Ocean sources, ocean sinks, and climate sensitivity. Global Biogeochem.
Cycles 10:175-190.

BASF. 1997. Basamid Granular sample label. BASF Corp., Research Triangle Park, N.C.

Becker J.O., H.D. Ohr, N.M. Grech, M.E. McGiffen, Jr., and J.J. Sims. 1998. Evaluation of methyl iodide as a soil fumigant in container and small field plot studies. Pesticide Sci. 52:58-62.

Carpenter, J., L. Lynch, and T. Trout. 2001. Township limits on 1,3-D will impact adjustment to methyl bromide phase-out. Calif. Agr. 55:(3)12-18.

Carter, C.A., J.A. Chalfant, R.E. Goodhue, F.M. Han, and M. DeSantis. 2005. The economic effects of the methyl bromide ban on the California strawberry industry. Rev Agr. Econ. (in press).

California Department of Food and Agriculture. 2002. Nursery inspection procedures manual 7, approved nematode certification program. 23 Apr. 2005 http://www.cdfa.ca.gov/phpps/pe/ nipm_pdfs/nipm_7.pdf.

California Department of Pesticide Regulation. 2003. Summary of pesticide use report data 2003: indexed by chemical. Calif. Dept. Pesticide Regulat., Sacramento. 5 Mar. 2005. http://www. cdpr.ca.gov/docs/pur/pur03rep/chmrpt03.pdf.

Crop Protection Reference. 2004. Telone C35 sample label, p. 957-960. In: 2004 Crop protection reference. C\&P Press, New York.

California Strawberry Commission. 1999. Crop profile of strawberries in California. National Pesticide Assessment Program. 18 June 2004. http://pestdata.ncsu.edu/cropprofiles/docs/castrawberries.html.

Crop Data Management System. 2004. Chloropicrin sample label. 18 June 2004. http://www.cdms. net/ldat/ld6GP000.pdf.

DeCal,A.,A. Martinez-Treceno, J.M. Lopez-Aranda, and P. Melgarejo. 2004a. Chemical alternatives to methyl bromide in Spanish strawberry nurseries. Plant Dis. 88:210-214.

DeCal, A., P. Melgarejo, A. Martinez-Treceno, T. Salto, M.L. Martinez-Beringola, J.M. GarciaBaudin, D. Garcia-Sinovas, E. Garcia-Mendez, M. Becerril, J.J. Medina, and J.M. Lopez-Aranda. 2004b. Chemical alternatives to MB for strawberry nurseries in Spain, 2003 results. Annu. Intl. Res. Conf. Methyl Bromide Alternatives and Emissions Reductions. Abstr. 17.

Duniway, J.M. 2002. Status of chemical alternatives to methyl bromide for preplant fumigation of soil. Phytopath. 92:1337-1343.

Duniway, J.M. and W.D. Gubler. 1996. Evaluation of some chemical and cultural alternatives to methyl bromide fumigation of soil in a California Strawberry production system. Annu. Intl. Res. Conf. Methyl Bromide Alternatives and Emissions Reductions. Abstr. 37.

Duniway, J.M., C.L. Xiao, and W.D. Gubler. 1998. Response of strawberry to soil fumigation: Microbial mechanisms and some alternatives to methyl bromide. Annu. Intl. Res. Conf. Methyl Bromide Alternatives and Emissions Reductions. Abstr. 6.

Eayre, C.G., J.J. Sims, H.D. Ohr, and B. Mackey. 2000. Evaluation of Methyl iodide for control of peach replant disorder. Plant Dis. 84:1177-1179.

Eitel, J. 1995. The effectiveness of dazomet as influenced by the use of plastic sheeting. Acta Hort. 382:76-85.

Fennimore, S.M. Haar and H. Ajwa. 2001. Alternative fumigant efficacy on weeds in strawberry nursery and fruiting fields. Annu. Intl. Res. Conf. Methyl Bromide Alternatives and Emissions Reductions. Abstr. 39.

Fritsch, H.J. and R. Huber. 1995. Basamid granular-A halogen-free soil disinfestant. Acta Hort. 382:76-85.

Harris, D.C. 1991. A comparison of dazomet, chloropicrin and methyl bromide as soil disinfestants 
for strawberries. J. Hort. Sci. 66:51-58.

Hokanson, S.C. and C.F. Finn. 2000. Strawberry cultivar use in North America. HortTechnology 10:94-106.

Johnson, A.W., S.M. McCarter, and R.E. Williams. 1979. Chemical control of nematodes and soilborne plant-pathogenic fungi on cabbage transplants. J. Nematol. 11:138-144.

Johnson, A.W. and J. Fledmesser. 1987. Nematicides: A historical review, p. 448-454; In J.A. Veech and D.W. Dickson (eds.). Vistase on nematology. Soc. Nematol., Hyattsville, Md.

Larson, K.D. 1994. Strawberry, p 271-297. In: B. Scheffer and P. C. Andersen (eds.) Handbook of environmental physiology of fruit crops. vol. 1. Temperate fruits. CRC Press, Boca Raton, Fla.

Larson, K.D. 1997. Nursery soil fumigation regime affects strawberry transplant production, transplant size and subsequent fruit yield. Annu. Intl. Res. Conf. Methyl Bromide Alternatives and Emissions Reductions. Abstr. 43.

Larson, K.D. and D.W. Shaw. 2000. Soil Fumigation and runner plant production: A synthesis of four years of strawberry nursery field experiments. HortScience 35:642-646.

Mappes, D. 1995. Spectrum of activity of dazomet. Acta Hort. 382:96-103.

Martin, F.N. 2003. Development of alternative strategies for management of soilborne pathogens currently control with methyl bromide. Annu. Rev. Phytopathol. 41:325-350.

National Agricultural Statistics Service. 2003. Veg- etable 2002 summary. Agr. Stat. Board, NASS, USDA, Wash., D.C.

National Oceanic and Atmospheric Administration. 2002. WMO/UNEP scientific assessment of ozone depletion: 2002.18 June 2004. http://www. al.noaa.gov/WWWHD/pubdocs/Assessment02/ executive-summary.html\#A1.

Noling, J.W. and J.O. Becker. 1994. The challenge of research and extension to define and implement alternatives to methyl bromide. J. Nematol. (Suppl.)26(4S):573-586.

Ohr, H.D., J.J. Sims, N.M. Grech, J.O. Becker, and M.E. McGiffen, Jr. 1996. Methyl iodide, an ozone safe alternative as a soil fumigant. Plant Dis. 80:731-735.

Park, B.S. and P.J. Landshoot. 2003. Effect of dazomet on annual bluegrass emergence and creeping bentgrass establishment in turf maintained as a golf course fairway. Crop Sci. 43:1387-1394.

Roby, D.M. and M.W. Melichar. 1997. 1,3-Dichloropropene regulatory issues, p. 25-31. In: J.N. Seiber, J.A. Knuteson, J.E. Woodrow, N.L. Wolfe, M.V. Yates, and S.R. Yates (eds.). Fumigants: Environmental fate, exposure, and analysis. Amer. Chem. Soc., Wash., D.C.

Shaw, D.V. and K.D. Larson. 1999. A meta-analysis of strawberry yield response to preplant soil fumigation with combinations of methyl bromide-chloropicrin and four alternative systems. HortScience 34(5):839-845.

Strand L.L. 1994. Integrated pest management for strawberries. Univ. Calif. Statewide Integrated Pest Mgt. Project, Div. Agr. Nat. Resour. Publ. 3351.

U.S. Department of Agriculture Economic Research Service. 2000. Economic implications of the methyl bromide phaseout. Agr. Info. Bul. 756.

U.S. Department of State. 2003. Methyl bromide critical use nomination of preplant soil use on strawberry nurseries in open fields or in protected environments. 18 June 2004. http://www.epa. gov/spdpublc/mbr/2004_USStrawberryNursery.pdf.

U.S. Environmental Protection Agency. 1993. Protection of stratospheric ozone. Fed. Reg. 58:15014-15049.

Voth, V. 1989. The effect of nursery location latitude on California winter planted strawberries. Acta Hort. 265:2883-2884.

Voth, V and RS. Bringhurst. 1990. Culture and physiological manipulation of California strawberries. HortScience 25:889-892.

Wilhelm, S 1966. Chemical treatments and inoculum potential of soil. Annu. Rev. Phytopathol. 4:53-78.

Wilhelm, S. andA.O. Paulus, 1980. How soil fumigation benefits the California strawberry industries. Plant Dis. 64:264-270.

Zhang, W.M., M.E. McGiffen, Jr., J.O. Becker, H.D. Ohr, J.J. Sims, and R.L. Kallenbach. 1997. Dose response of weeds to methyl iodide and methyl bromide. Weed Res. 37:181-189. 